\title{
Литология ястребовских отложений нижнего франа и связанные с ними титановые россыпи Воронежской антеклизы
}

\author{
C2020 А. В. Милаш ${ }^{凶}$ \\ Воронежский государственный университет, \\ Университетская пл. 1, 394018 Воронеж, Российская федерация
}

\begin{abstract}
Аннотация
Введение: Отложения ястребовской свиты нижнего франа содержат уникальные по генезису вулканогенно-осадочные россыпи титана, развитые на юго-востоке Воронежской антеклизы (BА). Они были описаны рядом авторов, но образования свиты в пределах всей этой палеозойской структуры остались недостаточно изученными. Этот пробел и восполняет настоящая статья.

Методика и фактический материал: Основным методом исследований отложений был литологофациальный. При построении фациальных карт использованы разрезы нескольких сотен скважин. Результаты и обсуждение: на основании подробной литологической характеристики основных типов ястребовских образований ВА показано, что их формирование практически на всей исследуемой территории происходило в прибрежно-морских и мелководно-морских условиях со слабой и средней активностью гидродинамического режима, а на юго-востоке антеклизы - также в лагунных и дельтовых условиях. Дана характеристика титаноносности вулканогенно-осадочных отложений на юго-востоке исследуемой территории.

Заключение: Ястребовские отложения формировались в условиях теплого гумидного климата при малоамплитудных тектонических движениях. Море трансгрессировало с востока, а с юга и запада шел снос терригенного материала. Характерной особенностью рассматриваемых образований является примесь в них содержащего ильменит пирокластического материала на юго-востоке ВА, поступавшего из действующих вулканов. Поэтому вулканогенно-осадочные породы свиты на данной территории являются титаноносными. Мощность вскрышных пород от 12-20 м до 181 м. Содержание условного ильменита от первых килограммов до 389 кг $\mathrm{M}^{3}$. Промышленная добыча погребенных титановых россыпей на сегодняшний день является нецелесообразной, вследствие сложных горнотехнических условий (большая мощность вскрыши, обводненность), но вполне могут извлекаться как сопутствующее полезное ископаемое при комплексном освоении имеющихся медно-никелевых месторождений и при разработке карьеров для получения гранитного щебня.
\end{abstract}

Ключевые слова: ястребовское время, вулканогенно-осадочные породы, фациальный анализ, ильменит, титановые россыпи.

Источник финансирования: Исследование выполнено при финансовой поддержке РФФИ в рамках научного проекта № 18-35-00115 мол_а.

Для циитирования: Милаш А. В. Литология ястребовских отложений нижнего франа и связанные с ними титановые россыпи Воронежской антеклизы // Вестник Воронежского государственного университета. Серия: Геология. 2020. №4. С. 26-35. DOI: doi.org/10.17308/geology.2020.4/3124

Контент доступен под лицензией Creative Commons Attribution 4.0 License.

${ }^{\bowtie}$ Милаш Алексей Васильевич, e-mail: pirit86@yandex.ru 


\section{Введение}

Отложения ястребовской свиты нижнего франа Воронежской антеклизы (ВА) распространены северо-восточнее линии г.г. Севск-Курск-Старый Оскол - Острогожск - Россошь (рис. 1) и с размывом залегают на подстилающих их живетских образованиях, а в единичных разрезах и на докембрийских породах. Кровля представлена толщей верхнедевонских, меловых и четвертичных отложений.

Современная граница распространения свиты близко совпадает с береговой линией морского бассейна ястребовского времени. Особенностью рассматриваемых отложений, отличающей их от других девонских образований, является наличие в них туфогенных пород на юго-востоке региона. Они содержат уникальные по генезису вулканогенно-осадочные россыпи титана, развитые на юго-востоке ВА. Они были описаны рядом авторов [1-3], однако, образования свиты в пределах всей этой палеозойской структуры остались недостаточно изученными. Этот пробел и восполняет настоящая статья.

Ястребовская свита впервые была выделена как «алевритово-каолиновая» пачка в основании нижнещигровских отложений В. Н. Преображенской в 1954 г. в районе Старого Оскола и Тима. В 1955 г. А. И. Ляшенко и С. В. Тихомиров выделили эти отложения в горизонт со стратотипом у с. Ястребовка у г. Старый Оскол. Принадлежность свиты к верхнему девону установлена В. Т. Умновой (1967) и Л. Г. Раскатовой (1969) по споровым комплексам [4].

Преобладающими отложениями ястребовской свиты являются пески, часто сцементированные в песчаники, алевриты, алевролиты и глины, часто с оолитами гидрогетит-сидерит-лептохлоритового состава. Пески и песчаники по составу делятся на три типа: слюдисто-кварцевые, олигомиктовые и вулканомиктовые. Аргиллитоподобные глины по составу преимущественно каолинитовые, в отдельных разрезах в заметных количествах присутствует хлорит [5]. Количество глин в направлении с юга на север и с запада на восток постепенно уменьшается. Мощность отложений колеблется от первых метров у границы выклинивания до 70 м на севере-востоке антеклизы

На юго-востоке ВА ястребовское время ознаменовалось проявлением эксплозивной вулканической деятельности, в связи с чем в разрезе ястребовской свиты на этой территории стали преобладать титаноносные вулканогенно-обломочные образования (>55\%) [6]. Они обогащены ильменитом и титаномагнетитом с преобладанием первого. Проявления сосредоточены в участках преимущественного развития девонских вулканитов, послуживших источником кластогенного рудоносного материала россыпей, в полосе шириной около 30 км, ориентированной в северо-западном направлении параллельно ЛосевскоМамонскому региональному разлому.

Основное внимание в статье посвящено проблеме реконструкции условий осадконакопления в ястребов- ское время на территории ВА и с использованием авторских данных приведена характеристика титаноносности вуканогенно-обломочных пород.

\section{Методика фациальных построений}

Составление фациальной карты ястребовского времени проводилось в два этапа: подготовительный и составительский. В подготовительный этап вёлся сбор и систематизация всего фактического материала, подготовка его для составления карты. В составительский этап в определенной последовательности и в соответствии с фактическим материалом отрабатывался наиболее оптимальный вариант модели карты. Проводились следующие операции по составлению карты: 1. Нанесение на карту точек выбранных разрезов и мощности (полной или неполной) отложений изучаемого стратиграфического интервала; 2. Построение карты изопахит - линий равных мощностей; 3. Выделение фациальных зон.

Метод литолого-фациального исследования заключался в комплексном изучении отложений, отражающих особенности седиментации. Изучались структурно-текстурные признаки, характеризующие динамику среды и способ осадконакопления, состав фауны, наличие авто- и аллохтонного органического вещества, свидетельствующего о глубине бассейна и близости континента, состав минеральных компонентов, отражающих источники сноса материала. Затем определялась принадлежность литотипов пород к группам фаций: IIII - морские; IV - переходные. В каждой из групп выделялись фациальные обстановки по типу гидродинамического режима в бассейне седиментации (для морских образований) и по типам обстановок (для переходных отложений). Полные разрезы с установленными кровлей и подошвой стратиграфического подразделения (горизонта), принимались за 100 \%. Затем проводился подсчет процентного соотношения мощностей различных литотипов в разрезах. При этом породы, слагающие менее $10 \%$ всего разреза, на картах не показаны. Границы резких изменений состава и типов пород в плане и в разрезе соответствуют границам фациальных зон. Литология пород показывается соответствующим знаком, фациальная обстановка - римской цифрой. Последовательность полос снизу вверх в элементарном разрезе отвечает хронологической последовательности наслоения пород. В соответствии с этим давались названия зон: первые цифры обозначают фациальную обстановку, буквы - гидродинамический режим. При чередовании нескольких литотипов в разрезе, между цифровыми индексами, обозначающими фациальные обстановки, ставится тире. В случае невозможности установления однозначного генезиса различных типов отложений, используется двойной индекс [7-9].

\section{Фациальные обстановки ястребовского времени Воронежской антеклизы}

Осадки ястребовского времени накапливались в прибрежно- и мелководно-морских зонах с различной гидродинамикой среды (рис. 1), обусловленной близостью берега и глубиной морского дна. Помимо этого, 

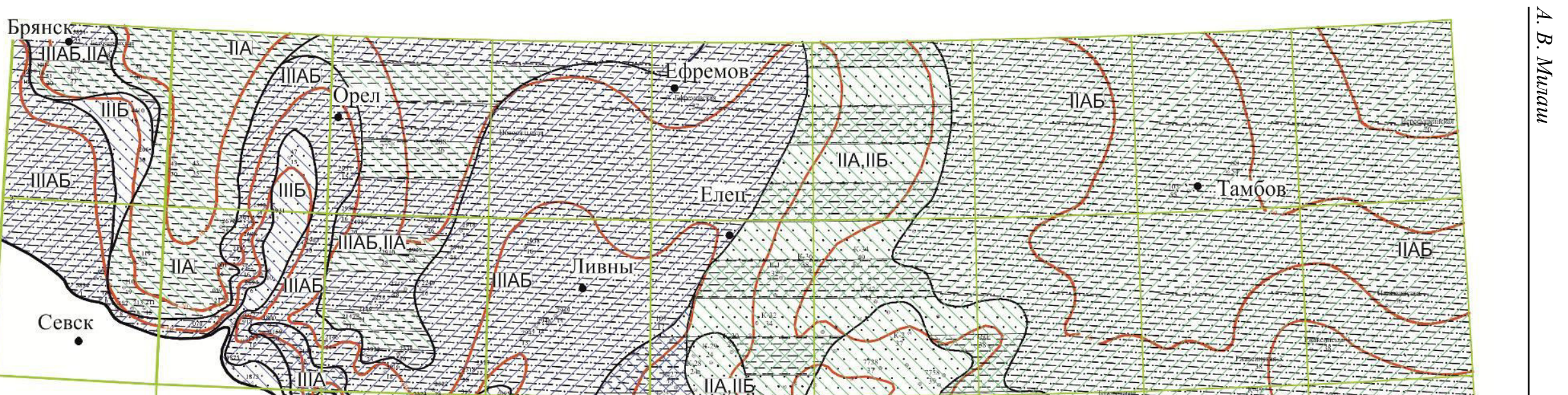

Условные обозначения

Фациальные обстановки:
1. Мелководно-морские, нормаль

\section{с активностью}

1115 средней

мбпаданием спабо

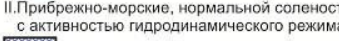

世睢 слабой

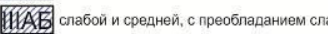

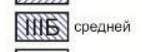

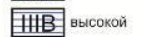

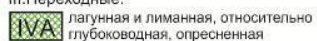

IV⿴囗十 пагунная и лиманная, мелководная

IVE

VIA $\square$ песчаник мелко-среднезернистьй $-\div$ алеврит

\section{-- аргиллитопо}

F5:

Прочие условные обозначения

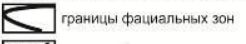

… границы фациальных подзон

5. озоожанити достоверные

T.

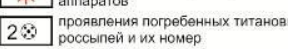

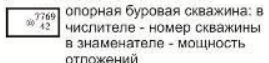

IIIB

Старый Оскол

A $=2.1$

IIA II $-2-2-2=1$

оронеж-

$\int_{-1-2-2-1}+1$

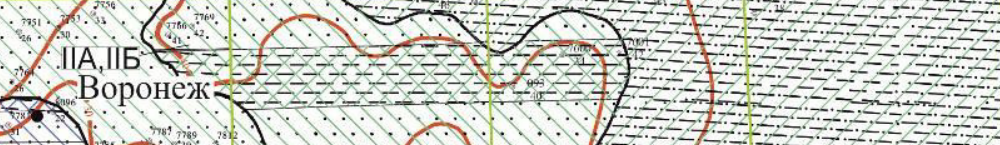

F

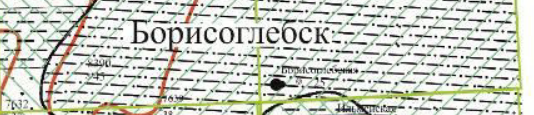
iां (3)

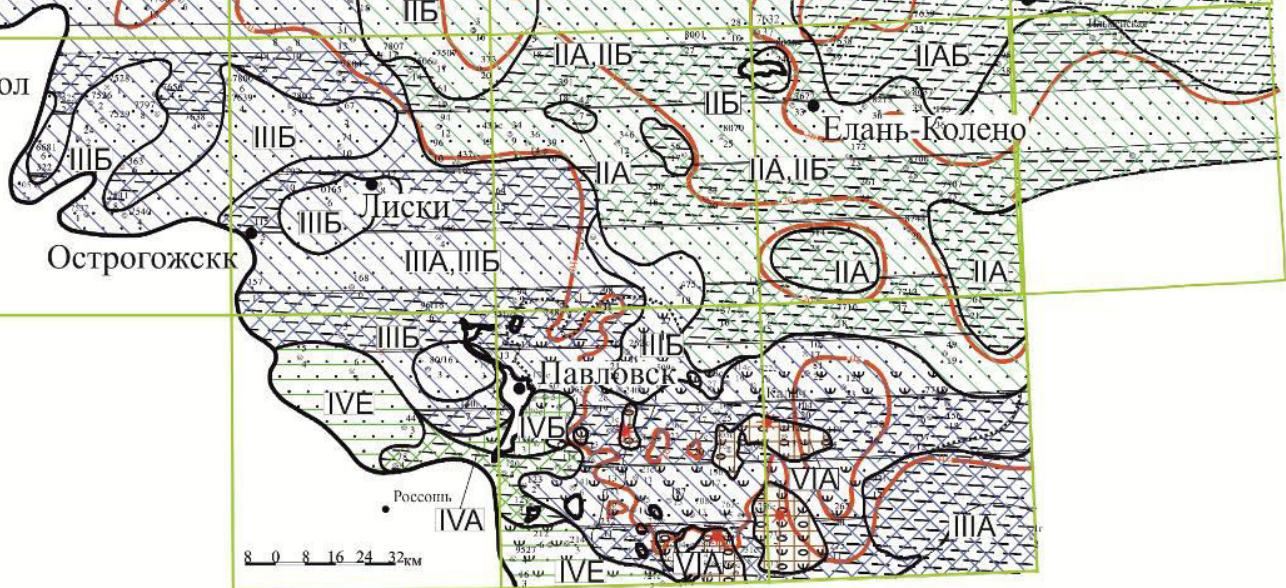

Рис.1. Фациальная карта Воронежской антеклизы. Ястребовское время.

[Fig.1. Facial map of the Voronezh anteclise. Yastrebovsk time.] 
накопление осадочного материала происходило в переходных зонах от морского бассейна к континенту [10].

Типичные мелководно-морские осадки формировались на северо-востоке Воронежской антеклизы (зоны ІІАБ и ІІА, ІІБ). Разрез в зоне ІІАБ представлен алевритистыми темно-, буровато-, зеленовато-серыми тонкослоистыми и неяснослоистыми аргиллитоподобными глинами, содержащими редкие раковины лингул и переслаивающимися с глинистыми алевролитами. Алевролиты серовато-белые или пестро окрашены в светло-, голубовато-серый и розовато-сиреневый цвета, кварцевые, иногда слабосцементированные, рыхлые до алевритов.

Разрез в фациальной зоне IIA, ІІБ сложен аргиллитами, песчаниками и алеврито-глинистыми породами, образовавшимися в мелководно-морских условиях слабой (IIA), а также средней гидродинамической среды (ІІБ). Здесь развиты переслаивающиеся пески, глины, песчаники, алевролиты, соотношение которых может меняться от скважины к скважине. Эти породы характеризуют морской режим с переменной активностью водной среды. Пески обычно тонко-, реже мелкозернистые серого, зеленовато-серого цвета с неясно выраженной слоистостью. Глины и алевролиты имеют такой же цвет, близкую к горизонтальной слоистость, взаимно переходят друг в друга, часто образуют тонкое переслаивание.

На северо-востоке исследуемой территории можно выделить ряд зон, связанных с локальными поднятиями и впадинами доястребовского рельефа. Впадины (зоны IIA), в основном, расположены вдоль южной границы фациальной зоны IIA, ІІБ. В них разрез сложен только аргиллитоподобными глинами с подчиненным содержанием алевролитов. Мощность глин во впадинах достигает 28 м. Поднятие (зона ІІБ) расположено на севере-западе от с. Елань-Колено. Разрез в данной зоне представлен тонко-мелкозернистыми слюдисто-кварцевыми песчаниками, мощностью до 24 м.

В центральной части территории, в пределах, повидимому, подводного поднятия, расположена зона распространения песчаных отложений (IІБ), представленная серыми и зеленовато-серыми мелкозернистыми кварцевыми песчаниками с глинистым цементом, имеющими горизонтальную и пологую косую слоистость. В западной части зоны развиты серовато-белые, реже охристо-желтые и голубовато-серые слюдистые тонкозернистые кварцевые, иногда полевошпатово-кварцевые пески.

В самой юго-восточной части территории распространены неслоистые жирные, в различной степени алевритистые глины, содержащие раковины брахиопод, рыбный детрит. Эта часть территории в ястребовское время располагалась в наиболее глубоководной части морского бассейна, со слабой активностью его гидродинамического режима (зона IIA).

Морские отложения также накапливались на северо-западе рассматриваемой площади, юго-восточнее г. Брянска, где в ястребовское время располагалась обширная впадина (зона IIA), в которой накапливались пестроцветные, красновато-коричневые, желтоватозеленовато-серые глины, плотные, неслоистые, жирные, аргиллитоподобные, слюдистые, в различной степени алевритистые и песчанистые с редкими прослоями алевролитов.

К западу и юго-западу от рассмотренных выше зон ІІАБ и ІІА, ІІБ располагаются разнообразные прибрежно-морские и лагунные фации.

В районе г.г. Малоархангельска и Брянска располагаются зоны ІІІАБ, ІІА, отложения в которых представлены ритмичным переслаиванием алевритов и аргиллитоподобных глин, описанных выше.

Обширную площадь исследуемой территории в районе г. Ливны, севернее г.г. Курска, Севска и Железногорска, занимает зона ІІІАБ, отложения которой сформировались в прибрежно-морских условиях со слабой и средней с преобладанием слабой активностью гидродинамического режима. Разрез в ней практически нацело сложен алевритами и алевролитами светло-серыми до белых (иногда каолинизированными), с различной примесью глинистого материала, слойками глин и железистыми оолитами.

Вблизи границы выклинивания распространены песчаные отложения, формировавшиеся в условиях средней (ІІІБ), активной (IIIB), а также средней и активной гидродинамических сред (ІІІБВ).

Западнее г. Павловска и вдоль всей границы распространения отложений фрагментарно отмечаются зоны ІІІБ, связанные с локальными поднятиями доястребовского рельефа. Разрез в зонах представлен песчаниками светло-серыми, слюдисто-кварцевыми, с примесью полевых шпатов, на юге исследуемой территории полевошпат-кварцевыми. Песчаники мелко-среднезернистые с глинистым (каолинитовым или иллиткаолинитовым) и известково-глинистым цементами. Данные отложения в районе г. Павловска содержат пепловый материал.

В центральной части территории, западнее и восточнее г. Курска, у границы выклинивания ястребовских отложений отмечаются зоны IIIB, которые указывают на высокую гидродинамику среды в прибрежной части ястребовского моря. Отложения этих зон представлены серыми грубозернистыми кварцевыми песчаниками с линзами переотложенных конгломератовидных железных руд.

В центральной и юго-восточной частях ВА располагается зона IIIA, ІІІБ, которая протягивается параллельно границе распространения отложений от с. Верхний Мамон на юге исследуемой территории до пгт. Касторное в центральной ее части. Разрез данной зоны представлен переслаиванием песчаников и аргиллитоподобных глин с подчиненным содержанием алевролита. Песчаники светло-серые, слюдисто-кварцевые, мелко-среднезернистые с глинистым (каолинитовым или иллит-каолинитовым) и известково-глинистым цементами. Глина серая с зеленоватым и буроватым оттенком, тонколистоватая, слабоалевритистая, с плохо выраженной горизонтальной слоистостью, изред- 
ка с присыпками песка кварцевого, слегка слюдистого по слоистости. На юго-востоке зоны, между г. Павловск, г. Калач и с. Верхний Мамон, выделяется подзона, отличающаяся наличием пеплового материала в песчаниках. Общая мощность пород до 20 м.

В вышеописанной фациальной зоне можно наблюдать участки с максимальными мощностями вулканогенных пород и наибольшей размерностью вулканогенно-обломочных пород, локализованных в виде разобщенных полей изометричной формы вблизи разломов, где существовали вулканические аппараты. Это зоны VIA, разрез которых представлен переслаиванием вулканогенно-обломочных пород и аргиллитоподобных глин, формировавшихся в прибрежно-морских (IIIA) условиях. Среди вулканогенно-обломочных пород выделяются вулканокластические (туфы, туффиты) и вулканогенно-осадочные (туфоконгломераты, туфогравелиты, туфопесчаники). Собственно, туфы составляют не более 10 \%, что свидетельствует о переработке вулканического материала в осадочном процессе. Особенностью вулканогенных отложений является наличие в них ильменита с преобладающим размером зерен 0.2-0.6 мм, тяготеющего к участкам с преобладанием вулканокластического материала и повышенным его содержанием в разрезах. Туфы (от 0.2 до 5 м) темно-зеленые, бурые (за счет ожелезнения), плотные или слабо сцементированные, состоят из обломков эффузивов, полевого шпата, ильменита, хромита, магнетита [5].

Туффиты темно-зеленые, зеленые, слоистые, часто слабо уплотненные, состоящие из обломков хлоритизированных эффузивов, кварца, полевого шпата, ильменита. Редко отмечаются обломки аргиллитов и сидерита. Характерно присутствие обломков углефицированной древесины. Туфоконгломераты, туфогравелиты и туфопесчаники серовато-зеленого, зеленого цвета с хлоритовым и хлорит-карбонатным цементом. Зерна кварца и полевого шпата, имеющие угловатые, оскольчатые и изометрические формы, преобладают (60-80 \%). Обломков эффузивов 10-30\%. Аргиллитоподобная глина, темно-серая, песчанистая, в виде линз и полос, плотная с грубоплитчатой отдельностью.

На юго-востоке исследуемой территории, вдоль границы распространения отложений, наблюдаются две фациальные зоны, представляющие собой конусы выноса речных отложений (зоны IVE). Породы в них представлены песчаниками (первые метры) зеленовато-серыми до темно-зеленых, разнозернистыми, от мелко- до крупнозернистых, косослоистыми, сцементированными глинисто-хлоритовой массой в фациальной зоне восточнее г. Россошь и имеющие глинистый цемент в зоне, расположенной севернее. В песчаниках присутствует большое количество углефицированных растительных остатков (УРО).

Между двумя конусами выноса в ястребовское время находилась лагуна (IVA), в которой формировались аргиллитоподобные иллит-каолинитовые глины серые, темно-серые в нижней части темно-бурые, с брекчиевидной текстурой и вкрапленностью сульфи- дов, плотные, тонкоплитчатые, со слабой горизонтальной слоистостью, жирные, с частыми углефицированными растительными остатками и пиритом.

Северо-восточнее зоны IVA располагается зона IVБ, представляющая собой бар или барьерный остров. Отложения в ней представлены песчаником (до 5 м) кварц-вулканомиктовым, зеленовато-серым с прослоями грязно-зеленого песчаника, горизонтальнослоистым, мелкозернистым на глинистом цементе с тонкорассеянным ильменитом, с УРО в виде стеблей растений

На юго-востоке исследуемой территории располагается зона IIIA, в разрезе которой преобладают аргиллитоподобные глины, а песчаники и алевролиты занимают подчиненное положение (не более $10 \%$ от мощности разреза). Глины аргиллитоподобные, серые, голубовато-серые, зеленовато-серые, с коричневыми разводами. В подошве слоя рассеяны мелкие кристаллики сидерита, в кровле - прослои среднезернистого песчаника на глинистом цементе. Глины местами очень сильно изрыты ходами илороющих организмов, заполненными мелкозернистым глинистым песчаником. Также в глинах присутствуют УРО.

\section{Проявления погребенных титановых россыпей на территории Воронежской антеклизы}

Ястребовское время ознаменовалось проявлением эксплозивной вулканической деятельности в юго-восточной части ВА, которая оказала существенное влияние на осадконакопление и определила особенный облик пород ястребовской свиты. Ястребовские образования здесь характеризуются наличием в разрезе вулканогенно-обломочных пород, наиболее грубые разности которых (средне- и крупнообломочные туфы, туфобрекчии, туфоконгломераты), накапливались вокруг центров извержений. Вулканогенно-обломочные породы распространены в зоне Лосевско-Мамонского разлома и оперяющих его нарушений, где наблюдаются в виде линз среди нормально-осадочных отложений [6]. Для разреза характерно чередование этих пород с нормально-осадочными отложениями - разнозернистыми до грубозернистых песчаниками, алевролитами и аргиллитами.

На юго-востоке исследуемой территории титаноносными являются широко распространенные туфопесчаники ястребовской свиты, обогащенные ильменитом, титаномагнетитом с преобладанием ильменита (присутствуют сидерит, лейкоксен, рутил, циркон, редко сфалерит). Мощность продуктивных туфопесчаников от 1-3 м до 13-20 м, нередко отмечается 2-3 рудоносных горизонта. Мощность вскрышных пород от 12-20 м (в Шкурлатовском гранитном карьере) до 181 м. Содержание условного ильменита от первых

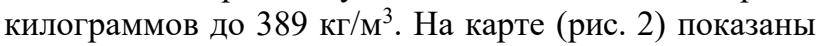
12 проявлений погребенных титановых россыпей с содержанием условного ильменита не менее 115-120 кг/м $\mathbf{M}^{3}$ (табл.1).

Крупность зерен ильменита от +0.1 до 0.05 мм, в основном менее 0.05 (93.5\%). Химический состав ильме- 


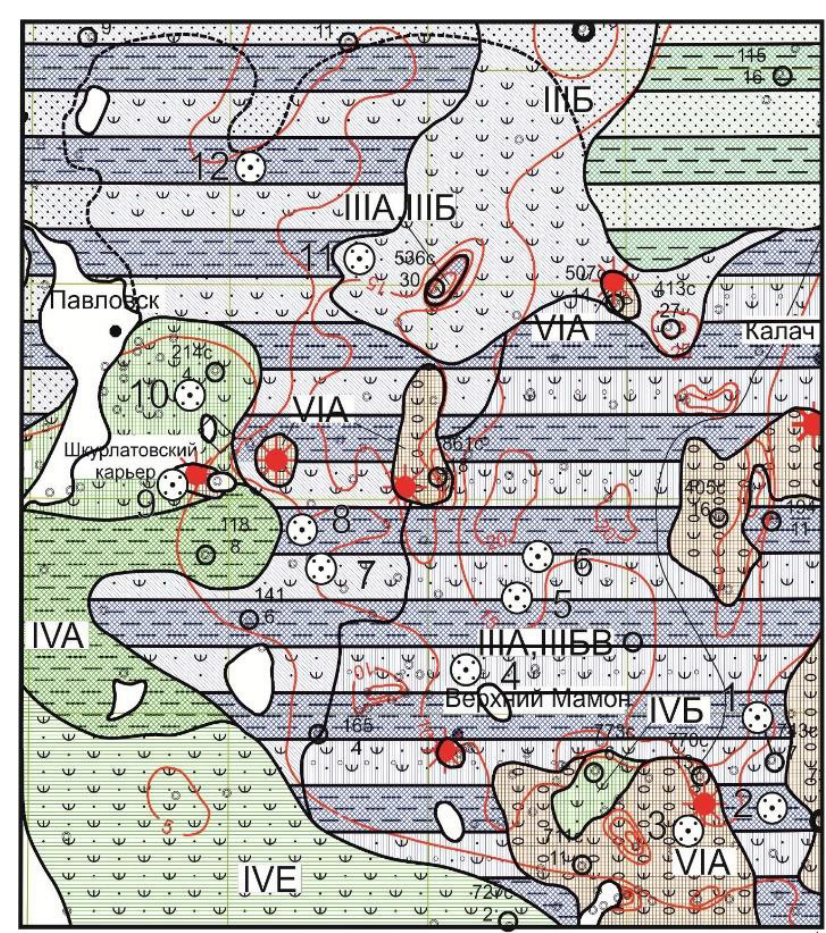

Рис. 2. Фациальная карта юго-восточной части Воронежской антеклизы. Ястребовское время. Условные обозначения на рис.1.
[Fig. 2. Facies map of the southeastern part of the Voronezh anteclise. Yastrebovsk time. Legend on Fig. 1.]

нита \%: $\mathrm{TiO}_{2}-45.6-48.8 ; \mathrm{FeO}-29.54-33.0 ; \mathrm{Fe}_{2} \mathrm{O}_{3}-$ 13.37-15.5; $\mathrm{MnO}-0.76-1.18 ; \mathrm{MgO}-1.0-4.66 ; \mathrm{SiO}_{2}-$ $0.46-2.1 ; \mathrm{Al}_{2} \mathrm{O}_{3}-0.9-1.12 ; \mathrm{Cr}_{2} \mathrm{O}_{3}-0.34-1.19 ; \mathrm{P}_{2} \mathrm{O}_{5}-$ 0.024-0.05; $\mathrm{V}_{2} \mathrm{O}_{5}$ - меньше $0.01 ; \mathrm{Nb}_{2} \mathrm{O}_{5}-0.075-0.08$.

Ястребовские отложения изучались на предмет алмазоносности (наличие пикроильменита и других минералов-спутников алмаза), однако положительных результатов не получено [12-14].

В настоящее время титановые россыпи не разрабатываются. На Шкурлатовском гранитном месторождении ястребовские отложения идут в отвалы, хотя по содержанию основных компонентов концентрат ильменита, получаемый из ястребовских туфогенных пород, вполне соответствует требованиям, предъявляемым металлургией.

Промышленная добыча погребенных титановых россыпей на сегодняшний день является нецелесообразной, вследствие сложных горнотехнических условий (большая мощность вскрыши, обводненность), но вполне могут извлекаться как сопутствующее полезное ископаемое при комплексном освоении имеющихся медно-никелевых месторождений, а также при разработке гранитных карьеров.

Табл.1. Характеристика проявлений титана на юго-востоке Воронежской антеклизы

[Table. 1. Characteristics of titanium manifestations in the southeast of the Voronezh anteclise]

\begin{tabular}{|c|c|c|c|c|}
\hline $\begin{array}{l}\text { № на карте } \\
\text { [No. on the } \\
\text { map] }\end{array}$ & $\begin{array}{c}\text { № } \\
\text { скважины } \\
\text { [Well No.] }\end{array}$ & $\begin{array}{c}\text { Мощность опробованного } \\
\text { продуктивного горизонта, м } \\
\text { [The thickness of the tested } \\
\text { productive horizon, m] }\end{array}$ & $\begin{array}{l}\text { Мощность } \\
\text { вскрыши, м } \\
\text { [Thickness of } \\
\text { stripping, } \mathrm{m} \text { ] }\end{array}$ & 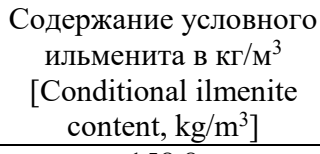 \\
\hline 1 & $743 \mathrm{c}$ & 2.2 & 181.0 & 158.8 \\
\hline 2 & $740 \mathrm{c}$ & 1.0 & 130.6 & 242.5 \\
\hline 3 & $774 \mathrm{c}$ & 1.2 & 89.2 & 180.0 \\
\hline 4 & 726 & 5.8 & 65.0 & 244.0 \\
\hline 5 & 536 & 12.0 & 49.6 & 389.0 \\
\hline 6 & 1106 & 1.0 & 96.0 & 362.0 \\
\hline 7 & 856 & 3.1 & 92.3 & 195.5 \\
\hline 8 & 826 & 3.2 & 92.5 & 205.5 \\
\hline 9 & Шкурлатовский карьер & $0.3-7 \mathrm{M}$ & $12-30$ & до 358.0 \\
\hline 10 & $203 c$ & 4.0 & 18.0 & 381.6 \\
\hline 11 & $279 \mathrm{c}$ & 6.6 & 140.0 & 370.0 \\
\hline 12 & $317 \mathrm{c}$ & 1.2 & 24.3 & 116.0 \\
\hline
\end{tabular}

\section{Заключение}

Анализ фациальных карт показывает, что ястребовские отложения Воронежской антеклизы формировались в различных условиях - лагунных, прибрежноморских, и в относительно удаленных от берега участках дна чрезвычайно мелководного эпиконтинентального морского бассейна. Максимальное разнообразие фациальных обстановок характерно для юго-восточной части исследуемой территории (рис. 3). Море двигалось с востока, северо-востока, а снос терригенного материала шел с юга и запада. Судя по составу ястребовских отложений, область сноса была сложена интенсивно выветрелыми среднедевонскими осадочными и докембрийскими кристаллическими породами
$[15,16]$. Характерной особенностью ястребовских образований является примесь в них пирокластического материала, поступавшего из действующих вулканов на юго-востоке ВА.

Титаноносными являются туфопесчаники. Мощность вскрышных пород на них от 12-20 м до 181 м. Содержание условного ильменита от первых килограммов до 389 кг/м³. Промышленная добыча погребенных титановых россыпей на сегодняшний день является нецелесообразной, вследствие сложных горнотехнических условий (большая мощность вскрыши, обводненность), но вполне могут извлекаться как сопутствующее полезное ископаемое при комплексном освоении имеющихся месторождений. 

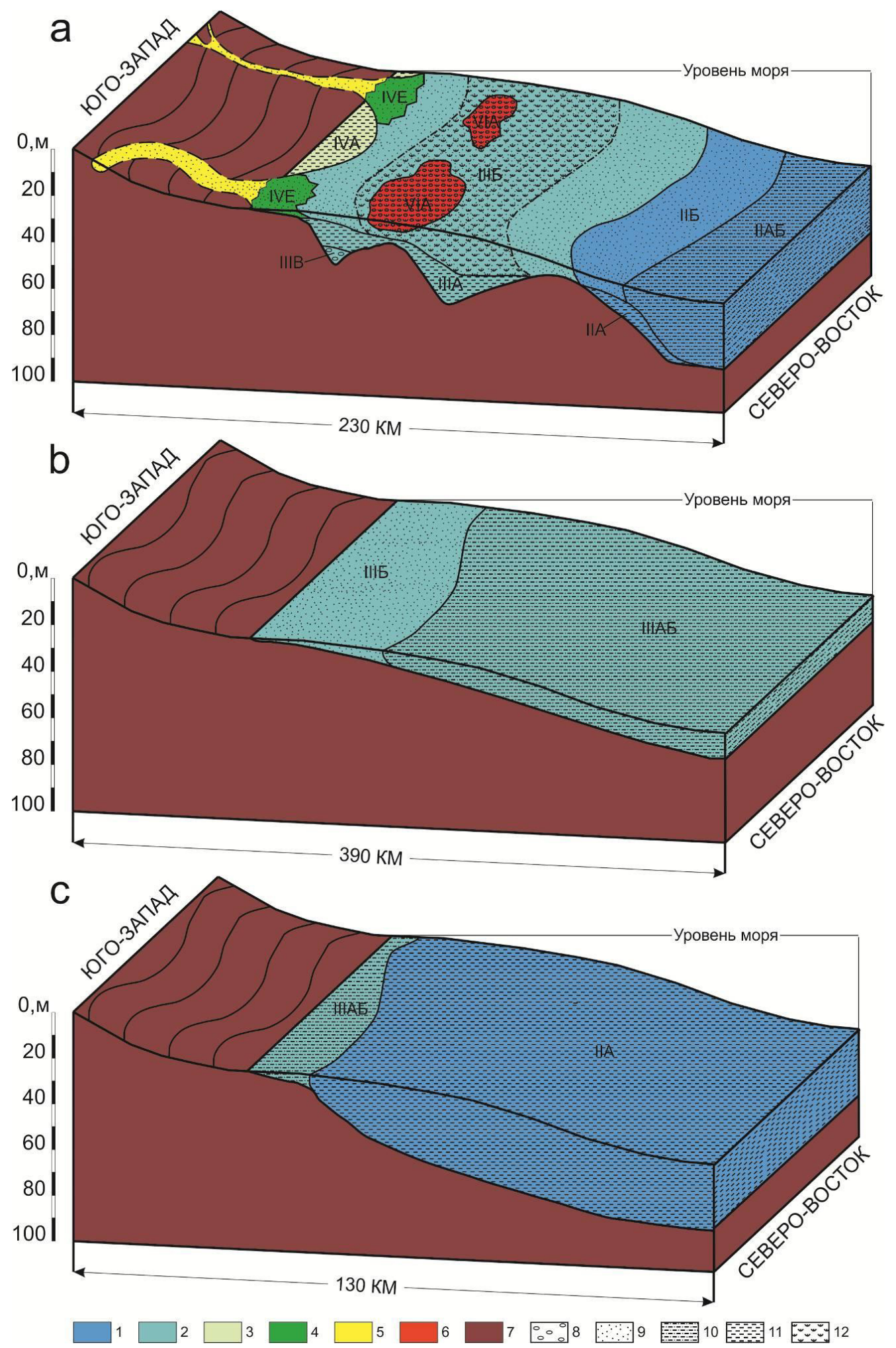

Рис. 3. Схемы седиментогенеза в ястребовское время для юго-восточной (a), центральной (b) и северо-западной (c) частей Воронежской антеклизы: 1 - мелководно-морские фациальные обстановки; 2 - прибрежно-морские фациальные обстановки; 3 лагунные фациальные обстановки; 4 - дельтовые фациальные обстановки; 5 - русловые фациальные обстановки; 6 - отложения вулканических построек; 7 - область сноса; 8 - галечники; 9 - пески и песчаники мелко-среднезернистые; 10 - глинистые алевриты и алевролиты; 11 - аргиллитоподобные глины; 12 - примесь туфогенного материала.

[Fig. 3. Schemes of sedimentogenesis in Yastrebovsk time for the southeastern (a), central (b) and northwestern (c) parts of the Voronezh anteclise: 1 - shallow marine facies environments; 2 - coastal marine facies environments; 3 - lagoon facies environments; 4 - delta facies environments; 5 - channel facies environments; 6 - deposits of volcanic structures; 7 - demolition area; 8 - gravels; 9 - sands and sandstones fine-grained; 10 - clayey siltstone and siltstone; 11 - argillite; 12 - admixture of tufogenic material.] 
Конфликт интересов: Автор декларирует отсутствие явных и потенциальных конфликтов интересов, связанных с публикацией настоящей статьи.

\section{ЛИТЕРАТУРА}

1. Милаш А. В. Литолого-фациальная характеристика ястребовских отложений юго-востока Воронежской антеклизы // Вестник Воронежского государственного университета. Серия: Геология. 2016. № 1. С. 37-43. URL: http://www.vestnik.vsu.ru/pdf/heologia/2016/01/2016-01-05.pdf (дата обращения: 29.11.2020)

2. Савко А. Д., Мануковский С. В., Мизин А. И, Бурыкин В. Н., Бартенев В. К., Окороков В. А., Бабкин В. Ф. Литология и фации донеогеновых отложений Воронежской антеклизы. Труды научно-исследовательского института геологии: Воронеж, Изд-во Воронеж. гос. ун-та. Вып. 3, 2001 201 c. URL: http://ниигвгу.pф/nauchnye-trudy/trudy-niig/ (дата обращения: 29.11 .2020$)$

3. Савко А. Д. Геология Воронежской антеклизы. Труды научно-исследовательского института геологии: Воронеж, Изд-во Воронеж. гос. ун-та. Вып. 12, 2002. 165 с. URL: $\mathrm{http}: / /$ ниигвгу.pф/nauchnye-trudy/trudy-niig/ (дата обращения: 29.11.2020)

4. Кононова Л. И., Овнатова Н. С., Ржосницкая М. А., Родионова Г. Д., Умнова В. Т., Федорова Т. И. Девон Воронежской антеклизы и Московской синеклизы. М.: Комитет РФ по геологии и использованию недр, 1995.265 c. URL: $\mathrm{http} / / / \mathrm{www} . g e o k n i g a . o r g /$ books/7307 (дата обращения: 29.11.2020)

5. Милаш А. В., Савко А. Д. Литология девонских отложений юго-востока Воронежской антеклизы. Труды научно-исследовательского института геологии: Воронеж, Изд-во Воронеж. гос. ун-та. Вып. 100, 2017. 131 с. URL: https://www.elibrary.ru/item.asp?id=30314171 (дата обращения: 29.11.2020)

6. Канцеров В. А. Ильменитоносные вулканогенно-осадочные породы позднего девона юго-востока Воронежской антеклизы: автореф. дис. ... канд. геол.-мин. наук: 04.00.21. Харьков, 1984. 23 с.

7. Савко А. Д., Мануковский С. В., Мизин А. И., Бурыкин В. Н., Бартенев В. К. Объяснительная записка к атласу фациальных карт Воронежской антеклизы. Труды научно-иссле- довательского института геологии: Воронеж, Изд-во Воронеж. гос. ун-та. Вып. 20, 2004. 107 с. URL: http://ниигвгу.pф/nauchnye-trudy/trudy-niig/ (дата обращения: 29.11.2020)

8. Виноградов А. П., Наливкин В. Д., Ронов А. Б., Хаин В. Е. Атлас литолого-палеогеографических карт Русской платформы и ее геосинклинального обрамления. М.-Л.: Государственное научно-техническое издательство литературы по геологии и охране недр, 1961. С. 65-69.

9. Hallam A. Facies interpretation and the stratigraphic record. W. H. Freeman and Co. Oxford. 1981. 304 pp.

10. Милаш А. В. Литология и фации ястребовских отложений присводовой части Воронежской антеклизы. // Вестник Воронежского государственного университета. Серия: Геология. 2020. № 1. С. 59-65.

DOI: https://doi.org/10.17308/geology.2020.1/2514 (дата обращения: 29.11.2020)

11. Милаш А. В. Фациальные особенности формирования титановых россыпей нижнего франа Воронежской антеклизы. // Вестник Воронежского государственного университета. Серия: Геология. 2013. № 1. С. 219-222. URL: http://www.vestnik.vsu.ru/pdf/heologia/2013/01/2013-01-29.pdf (дата обращения: 29.11.2020)

12. Савко А. Д. Шевырев Л. Т., Ильяш В. В. Ассоциация минералов-индикаторов алмазоносности в осадочном чехле Воронежской антеклизы // Проблемы алмазной геологии и некоторые пути их решения. Воронеж, 2001. С. 423-433.

13. Черешинский А. В., Савко А. Д. Акцессорные минералы базальных горизонтов Воронежской антеклизы (в связи с вопросами алмазоносности). Тр. науч.-исслед. ин-та геологии Воронеж. ун-та. Вып. 48. Воронеж, 2007. 120 с.

14. Черешинский А. В. Минералы-индикаторы кимберлитов палеозойского промежуточного коллектора Воронежской антеклизы // Вестник Воронежского государственного университета. Серия: Геология. 2016. № 1. С. 76-82.

15. Савко А. Д. Фанерозойские коры выветривания и связанные с ними отложения Воронежской антеклизы, их неметаллические полезные ископаемые: автореф. дис. ... докт. геол.мин. наук: 25.00.06. Воронеж, 1984. $31 \mathrm{c}$.

16. Савко А. Д., Хожаинов Н. П. Этапы формирования кор выветривания в верхнем протерозое и палеозое Воронежской антеклизы. Литогенез в докембрии и фанерозое воронежской антеклизы. Воронеж: Изд-во ВГУ, 1975. С. 46-59. 
UDC 551.83(470.32)

DOI: https://doi.org/10.17308/geology.2020.4/3124

ISSN 1609-0691

Received: 27.11 .2020

Accepted: 01.12.2020

Published online: 18.12 .2020

\title{
Lithology of the Yastrebovsk deposits of the Lower Frasnian age and associated titanium placers of the Voronezh anteclise
}

\author{
(C)2020 A. V. Milash ${ }^{\bowtie}$ \\ Voronezh State University, \\ 1 Universitetskaya pl., Voronezh 394018, Russian Federation
}

\begin{abstract}
Introduction: Deposits of the Yastrebovsk suite of the Lower Frasnian age contain volcanic-sedimentary titanium placers, unique in genesis and formed in the south east of the Voronezh anteclise (VA). A number of studies focus on the deposits, but the suite formed within the entire Paleozoic structure has not been thoroughly studied yet. The aim of this article is to fill this gap.

Methodology: The deposits were studied using the lithological and facies analysis. The facie maps were based on the sections of several hundred wells.

Results and discussion: The results of a detailed lithological characterization of the main types of Yastrebovsk deposits demonstrated that the formation of the studied sediments practically all over the studied territory occurred under coastal-marine and shallow-marine conditions with weak and medium activity of the hydrodynamic regime. In the south east of the Voronezh anteclise the formation occurred under lagoon and delta conditions. The article describes the characteristics of the titanium content of volcanic-sedimentary deposits in the south east of the studied area.

Conclusions: Yastrebovsk deposits were formed under a warm moist climate with low-amplitude tectonic movements. The sea transgressed from the east, and ablation of terrigenous material occurred from the south and west. A characteristic feature of the studied deposits is an admixture of ilmenite-containing pyroclastic material from active volcanoes in the south east of the VA. Therefore, the volcanic-sedimentary rocks of the suite in this area are titanium-bearing. The thickness of the overburden is from $12-20 \mathrm{~m}$ to 181 $\mathrm{m}$. The content of conditional ilmenite ranges from the a few kilograms to $389 \mathrm{~kg} / \mathrm{m}^{3}$. At the moment, industrial extraction of buried titanium placers is impractical due to the difficult mining conditions (high overburden capacity, water cut). However, they may well be extracted as an accompanying mineral during the integrated development of the existing copper-nickel deposits as well as during the development of open pits in order to obtain granite crushed stone.
\end{abstract}

Keywords: Yastrebovsk time, volcanic-sedimentary rocks, facies analysis, ilmenite, titanium placers.

Funding: The study was supported by the Russian Foundation for Basic Research, project no. 18-35-00115 mol_a.

For citation: Milash A. V. Lithology of the Yastrebovsk deposits of the Lower Frasnian age and associated titanium placers of the Voronezh anteclise. Vestnik Voronezhskogo gosudarstvennogo universiteta. Seriya: Geologiya $=$ Proceedings of Voronezh State University. Series: Geology, 2020, no.4, pp. 26-35. DOI: doi.org/10.17308/geology.2020.4/3124

Conflict of interests: The authors declare the absence of obvious and potential conflicts of interest related to the publication of this article

The content is available under Creative Commons Attribution 4.0 License.

Alexei V. Milash, e-mail: pirit86@yandex.ru 


\section{REFERENCES}

1. Milash A. V. The litologo-facial characteristic of jastrebovsk sediments of the southeast of Voronezh antecline. Vestnik Voronezhskogo gosudarstvennogo universiteta. Seriya: Geologiya $=$ Proceedings of Voronezh State University. Series: Geology, 2016, no. 1, pp. 37-43. URL: http://www.vestnik.vsu.ru/pdf/ heologia/2016/01/2016-0105.pdf (accessed: 29 November 2020). (In Russ., abstract in Eng.) 2. Savko A. D, Manukovski S. V., Mizin A. I., Burikin V. N., Bartenev V. K., Okorokov V. A., Babkin V. F. Litologia I facii doneogenovih onlozhenii Voronezhskoi anteklizi. [Lithologi and facies of the Voronezh anteclise pre-neogene deposites]. Trudy Nauchno-issledovatel'skogo Instituta Geologii [The work of the Research Institute of Geology], Voronezh, VSU Publ., 2001, vol. 3, 201 p. URL: http://ниигвгу.pф/nauchnye-trudy/trudy-niig/ (accessed: 29 November 2020). (In Russ., abstract in Eng)

3. Savko A. D. Geologia Voronezhskoi anteklizi. [Geology of the Voronezh Antecline]. Trudy Nauchno-issledovatel'skogo Instituta Geologii [The work of the Research Institute of Geology], Voronezh, VSU Publ., 2002, vol.12, 165 p. http://ниигвгу.pф/nauchnye-trudy/trudy-niig/ (accessed: 29 November 2020). (In Russ.)

4. Kononova L. I., Ovnatova N. S., Rzhosnitskaya M. A., Rodionova G. D., Umnova V. T., Fedorova T. I. Devon Voronezhskoi anteklizi i Moskovskoi sineklizi. [The Devonian of the Voronezh anticline and the Moscow synklin]. Moscow, Komitet RF po geologii i ispolzovanii nedr, 1995, 265 p. URL: http://www.geokniga.org/books/7307 (accessed: 29 November 2020). (In Russ., abstract in Eng)

5. Milash A. V., Savko A. D. Litologia devonskih onlozheniy ugo-vostoka Voronezhskoy anteclizi. [Lithologi of the Devonian deposits of the south-east of the Voronezh antecline]. Trudy Nauchno-issledovatel'skogo Instituta Geologii [The work of the Research Institute of Geology], Voronezh, VSU Publ., vol. $100,2017.131$ p. URL: https://www.elibrary.ru/item.asp?id=30314171 (accessed: 29 November 2020). (In Russ., abstract in Eng)

6. Kanzerov V. A. Ilmentionosniivulkanogenno-osadochnie porodi pozdnego devona ugo-vostoka Voronezhskoi anteklizi. Dis. kand. geol.-min. nauk [Ilmenitonous volcanic-sedimentary rocks of the late Devonian of the southeast of the Voronezh ante-cline. Extended Abstract of Ph.D. Thesis]. Kharkiv, 1986. 23 p. (In Russ.).

7. Savko A. D, Manukovski S. V., Mizin A. I., Burikin V. N., Bartenev V. K. Objasnitelnaja zapiska $\mathrm{k}$ atlasu facialnih kart Voronezhskoi anteklizi. [Explanatory memorandum to the facies maps atlas of the Voronezh anteclise]. Trudy Nauchnoissledovatel'skogo Instituta Geologii [The work of the Research Institute of Geology], Voronezh, VSU Publ., vol. 20, 2004, 107 p. URL: http://ниигвгу.pф/nauchnye-trudy/trudy-niig/ (accessed: 29 November 2020). (In Russ., abstract in Eng)

8. Vinogradov A. P., Nalivkin V. D., Ronov A. B., Hain V. E. Atlas litologo-paleograficheskih kart Russkoy platformi $i$ ee geosinklinalnogo obramlenia. [Atlas of the lithologicalpaleogeo-graphical maps of the Russian platform and its geosynclinals framing]. M-L. State Scientific and Technical Publishing House of Literature on Geology and Mineral Protection, 1961. pp. 65-69.

9. Hallam A. Facies interpretation and the stratigraphic record. W. H. Freeman and Co. Oxford. 1981. 304 pp.

10. Milash A. V. Lithology and facies of Yastrebovsk deposits of the crestal part of the Voronezh Anteclise. Vestnik Voronezhskogo gosudarstvennogo universiteta. Seriya: Geologiya $=$ Proceedings of Voronezh State University. Series: Geology, 2020, no. 1, pp. 59-65. DOI: https://doi.org/10.17308/geology. 2020. $1 / 2514$

11. Milash A. V. Facial features of the formation of titanium placers of the Lower Frans of the Voronezh anteclise. Vestnik Voronezhskogo gosudarstvennogo universiteta. Seriya: Geologiya $=$ Proceedings of Voronezh State University. Series: Geology, 2013, no. 1, pp. 219-223. URL: http://www.vestnik.vsu.ru/pdf/heologia/2013/01/2013-01-29.pdf (accessed: 29 November 2020) (In Russ., abstract in Eng.).

12. Savko A. D. Assotsiatsiya mineralov-indikatorov almazonosnosti v osadochnom chekhle Voronezhskoy anteklizy [Associations of the minerals-indicators in the sedimentary cover of the Voronezh anteclyse]. Problems of diamond geology and some ways of their solution. Voronezh, 2001, pp. 423-433. (accessed: 29 November 2020) (In Russ., abstract in Eng.).

13. Chereshinskii A. V. Aktsessornyye mineraly bazal'nykh gorizontov Voronezhskoy anteklizy ( $\mathrm{v}$ svyazi $\mathrm{s}$ voprosami almazonosnosti). [The accessory minerals of horizon basal of Voronezh anteclise (in bonding with questions diamondiferousness)]. Trudy Nauchno-issledovatel'skogo Instituta Geologii [The work of the Research Institute of Geology], Voronezh, VSU Publ., vol. 48, 2007, 120 p. URL: https:// http://ниигвгу.pф/nauchnye-trudy/trudy-niig/ (accessed: 29 November 2020). (In Russ., abstract in Eng)

14. Chereshinskii A. V. Mineraly-indikatory kimberlitov paleozoyskogo promezhutochnogo kollektora Voronezhskoy anteklizy. [The indicator minerals of kimberlites of paleozoic intermediate placer trap of the Voronezh anteclyse]. Vestnik Voronezhskogo gosudarstvennogo universiteta. Seriya: Geologiya = Proceedings of Voronezh State University. Series: Geology, 2016, no. 1, pp. 76-82. URL: http://www.vestnik.vsu.ru/pdf/heologia/2016/01/2016-01-10.pdf (accessed: 29 November 2020) (In Russ., abstract in Eng.).

15. Savko A. D. Fanerozoyskiye kory vyvetrivaniya i svyazannyye s nimi otlozheniya Voronezhskoy anteklizy, ikh nemetallicheskiye poleznyye iskopayemyye. Dis. dokt. geol.-min. nauk [Phanerozoic weathering crust and associated deposits of the Voronezh anteclise, their non-metallic minerals. Extended Abstract of D.sc Thesis]. Moscow, 1985, 31 p. (In Russ.).

16. Savko A. D., Khozhainov N. P. Etapy formirovaniya kor vyvetrivaniya $\mathrm{v}$ verkhnem proterozoye i paleozoye Voronezhskoy anteklizy [Stages of weathering crust formation in the Upper Proterozoic and Paleozoic of the Voronezh anteclise]. Litogenez $v$ docembrii I fanerozoye Voronezhskoy anteklizy. Voronezh, 1975, pp. 46-59. (In Russ.).
Милаш Алексей Васильевич - к. г.-м. н., доцент, Воронежский государственный университет, Воронеж, Российская Федерация; E-mail: pirit86@yandex.ru; ORCID https://orcid.org/0000-0002-2956-3021

Автор прочитал и одобрил окончательный вариант рукописи.
Alexey V. Milash - PhD in Geol.-Min., associate professor, Voronezh State University, Voronezh, Russian Federation; E-mail: pirit86@yandex.ru; ORCID https://orcid.org/0000-0002-2956-3021

Author have read and approved the final manuscript. 